\title{
PERANCANGAN SISTEM INFORMASI DATA KEPENDUDUKAN BERBASIS WEB PADA KELURAHAN LOKOBOKO KECAMATAN NDONA
}

\author{
Astria Binti Musa', Stefania Baptis Seto르, Sofia Sa'o ${ }^{3}$, Finsensius Yesekiel Naja ${ }^{4}$, \\ Agustina Mei ${ }^{5}$, Ningsih' ${ }^{6}$, Maria Trisna Sero Wondo ${ }^{7}$, Maria Fatima $\mathrm{Mei}^{8}$ \\ 1,2, 3, 4, 5, 6, 7, 8 Universitas Flores, Ende, Indonesia \\ *Penulis Koresponsensi, email: stefaniseto@gmail.com
}

Received:20/12/2021

Revised:07/01/2022

Accepted:09/01/2022

\begin{abstract}
The problem found in Lokoboko Village, Ndona sub-district is that village data input is still done manually and has not been regulated properly, therefore this community service program is very good for changes in village data management that has been carried out by village officials. With the design of this Web-based data information system, it is very easy for village officials to input and manage population data. The purpose of this service activity is to provide convenience to village officials in filling village data using the HTML website. The method used in this service activity is socialization, assistance and training to village officials in using HTML Web sites. The results obtained are that data taken from the community is inputted via a web created and the data is well organized so that it can be presented neatly.
\end{abstract}

Keywords: Information System Design, Village data management

\begin{abstract}
Abstrak. Permasalahan yang ditemukan di Desa Lokoboko Kecamatan Ndona adalah pengelolaan data desa tepatnya penginputan data desa masih dilakukan secara manual dan belum diatur dengan baik, maka dari itu program pengabdian kepada masyarakat ini sangat baik untuk perubahan pengelolaan data desa yang selama ini dilakukan oleh aparat desa. Dengan adanya perancangan sistem informasi data berbasis web ini sangat memudahkan aparat desa dalam menginput dan mengelola data kependudukan. Tujuan dari kegiatan pengabdian ini adalah untuk memberikan kemudahan kepada aparat desa dalam pengisian data desa menggunakan website HTML. Metode yang digunakan dalam kegiatan pengabdian ini adalah sosialisasi, pendampingan dan pelatihan kepada aparat desa dalam menggunakan Website HTML. Hasil yang didapat adalah data yang diambil dari masyarakat diinput melalui web yang dibuat dan data tersebut tertata dengan baik sehingga dapat tersaji dengan rapi.
\end{abstract}

Kata Kunci: Perancangan Sistem Informasi, Pengelolaan Data Desa

How to Cite: Musa, A. B., Seto, S.B., Sa'o, S., Naja, F.Y., Mei, A., Ningsih, N., Wondo, M. T. S., \& Mei, M.F. (2022). Perancangan Sistem Informasi Data Kependudukan Berbasis Web pada Kelurahan Lokoboko Kecamatan Ndona. Mitra Mahajana: Jurnal Pengabdian Masyarakat, 3(1), 34-40. doi: https://doi.org/10.37478/mahajana.v3i1.1488

\section{PENDAHULUAN}

O’Brien \& Marakas (2010), menyatakan bahwa pengertian Sistem Informasi merupakan kombinasi teratur dari orang-orang, hardware, software, jaringan komunikasi dan sumber daya yang mengumpulkan, mengubah, dan menyebarkan informasi dalam sebuah organisasi. Lebih lanjut Sopiandi (2020), mendefenisikan Teknologi informasi merupakan faktor yang sangat mendukung dalam penerapan sistem informasi dan merupakan suatu solusi intansi dan manajemen untuk memecahkan permasalahan manajemen dan akuntansi yang timbul dalam praktiknya. Teknologi informasi merupakan organisasi terdiri dari perangkat keras, perangkat lunak, perangkat telekomunikasi, manajemen basis data, dan teknologi lain yang digunakan untuk menyimpan data dan membuat data tersedia dalam bentuk informasi kepada pembuat keputusan. Berdasarkan pengertian diatas maka dapat disimpulkan bahwa sistem informasi adalah suatu perangkat elemen atau komponen yang terdirti dari hardware dan software yang digunakan untuk mengumpulkan, mengelolah, menyimpan, mengubah dan menyebarkan informasi.

Sistem informasi adalah suatu perangkat elemen atau komponen yang saling terkait satu sama lain, yang dapat mengumpulkan, mengelolah, menyimpan dan juga menyebarkan data dan 
informasi serta mampu untuk memberikan feedback untuk memenuhi tujuan suatu organisasi (Stair \& Reynolds 2010). Di era kemajuan globalisasi dan teknologi dunia, system informasi merupakan syarat penting yang terus diperbaharui dan dituntut untuk mudah diakses dan bersetuhan langsung dengan masyarakat terutama dalam pelayanan public (Nugroho \& Mulyana, 2018). Wilayah Kelurahan, tentu menjadi salah satu komunitas yang pelayanannya sangat dengan dengan masyarakat, pasti turut dituntut untuk bisa meyesuaikan dengan keadaan kemajuan teknologi tersebut (Siti \& Witi, 2021).

Namun dalam penyesuaiaannya, masalah yang timbul dan dihadapi adalah minimnya tingkat ketrampilan aparatur setempat dengan tuntutan masyarakat yang lebih dinamis serta sistem pengelolaan arsip masih bersifat konvensional memicu resiko tinggi. Sejalan dengan agenda reformasi dari Kementerian Pemberdayaan Aparatur Negera dan Reformasi Birokrasi bahwa setiap individu dan organisasi dituntut untuk mengembangkan diri guna meningkatkan pelayanan masyarakat (Azi \& Anggraini, 2018) (Hasan, et. al., 2021). Pengelolaan administrasi dan arsip yang konvensional harus diubah menjadi berbasis sistem dan digital. Selain itu Desa juga perlu mempublikasikan seluruh potensi yang dimilikinya sehingga masyarakat semakin mudah untuk mendapatkan informasi tentang desa, disamping perlu untuk melukan transparansi public (Hidayatulloh \& Mulyadi, 2015) (Rozi \& Listiawan, 2017).

Kelurahan Lokoboko merupakan salah satu Keluruhan yang berada di Kecamatan Ndona Kabupaten Ende. Penduduk Kelurahan Lokoboko sebanyak 1.874 orang dari 452 KK Jiwa. Penduduk Kelurahan Lokoboko umumnya bergerak di bidang Pertanian Dan Batu Merah. Kurang lebih penduduknya berprofesi sebagai petani, Tenun Ikat, dan Pekerja Swasta. Petani di Kelurahan Lokoboko masih belum mampu meminimalisir biaya pertanian dengan membuat pupuk organic, atau membuat inovasi baru di bidang pertanian dengan menanam bibit baru yang unggul.

Menyadari bahwa kebutuhan teknologi informasi sangat besar manfaatnya, maka dibutuhkan sebuah system yang harus diterapkan pada kelurahan Lokoboko. Dengan adanya sistem informasi pengelolaan data bantuan berbasis web sangatlah diperlukan untuk mengurangi keresahan dan kesalahan-kesalahan dalam mengatasi penginputan data (Hayat, Retnadi \& Gunadi, 2016) (Riyadi, 2021). Sehingga kebijakan-kebijan yang akan diambil oleh pemerintah sangatlah transparan dan bisa dipantau langsung oleh masyarakat (Karim \& Purba, 2018).

Salah satu solusi yang dapat diberikan kepada pengelolaan data desa ini ialah perancangan sistem informasi data kependudukan berbasis web. Menurut Purwanti dalam Andoyo \& Sujarwadi, 2015) Website atau situs juga dapat diartikan sebagai kumpulan halaman yang menampilkan informasi dat teks, data gambar diam atau bergerak, data animasi suara, vidio atau gabungan dari semuanya, baik yang bersifat statis maupun dinamis yang membentuk suatu rangkaian bangunan yang saling terkait dimana masing-masing dihubungkan dengan jaringan-jaringan halaman. Aplikasi berbasis web adalah aplikasi yang dikembangkan menggunakan bahasa HTML, PHP, CSS, JS yang membutuhkan web server dan browser untuk menjalankannya seperti Chrome, Firefox atau Opera. Aplikasi Web dapat berjalan pada jaringan internet maupun intranet (Jaringan LAN), Data terpusat dan kemudahan dalam akses adalah ciri utama yang membuat Aplikasi Web lebih banyak diminati dan lebih mudah diimplementasikan pada berbagai bidang kehidupan, (Adani 2018).

Website yang digunakan dalam hal ini adalah HTML. Semua format dokumen hyperlink yang dapat di klik gambar, dokument, multimedia, form yang dapat diisi di dasarkan atas HTML. HTML terdiri dari kombinasi teks dan simbol yang disimpan dalam sebuah file. Dalam membuat file HTML, terdapat standar atau format khusus yang harus diikuti. Format tersebut telah tertuang dalam standar kode internasional, (Andoyo \& Sujarwadi, 2014) (Aprilia 2018). Selain itu HTML memiliki struktur yang fleksibel, tanpa lojik serta toleran terhadap kesalahan, Standar Minimum elemen HTML; Document Type Declaration (DTD), Head dan Body, (Almais 2018). Setiap menggunakan HTML dalam membuat web diperlukan juga syntax PHP, dengan 
menggunakan PHP user tidak akan melihat kode-kode PHP yang telah ditulis tersebut di dalam browser. Umumnya semua dokumen web dibagi menjadi dua. Section (bagian), yaitu section head, dan section body.

\section{METODE PELAKSANAAN}

Metode yang digunakan dalam kegiatan pengabdian ini adalah sosialisasi, pendampingan dan pelatihan kepada apparat desa dalam menggunakan aplikasi system informasi berbasis Web. Kegiatan pengabdian ini menyajikan model aplikasi berbasis web pada pengelolaan data dan informasi pada kelurahan Lokoboko. Sosialisasi tentang pentingnya menggunakan system informasi dapat membantu aparat desa dalam menginput dan menyimpan data serta menampilkan informasi bagi warga masyarakat. Kegiatan pendampingan dan pelatihan pada apparat desa dilakukan untuk pengisian data dengan menggunakan rancangan aplikasi system infomasi berbasis web yang ditawarkan.

Adapun materi yang diberikan selama sosialisasi dan pendampingan diantaranya adalah pengenalan sistem infomasi berbasis Web HTML, bagaimana cara menginput data dan menyiapkan data yang berisikan informasi.

\section{HASIL DAN PEMBAHASAN}

Sistem informasi dan administasi kependudukan pada Kelurahan Lokoboko Nodna masih dilakukan secara manual. Karena pengelolaannya yang masih dilakukan secara konvensional, maka system pendataan masih sering terjadi kesalahan dalam selisih dan duplikasi data. Pengembangan sistem informasi berbasis web berupa sistem Administrasi Kependudukan berbasis web pada Kelurahan Lokoboko merupakan sistem yang memberikan informasi mengenai data penduduk yang membantu kecepatan dan kualitas dalam penyampaian informasi serta mempermudah dalam pelayanan cetak surat-menyurat agar lebih efektif dan efisien (Imaniawan \& Wati, 2017). Sistem Informasi data kependudukan berbasis web ini juga mempunyai kemampuan yang baik jika diterapkan, karena selain otomatis, akan mudah untuk di kontrol jika terjadi kesalahan ataupun pendobelan data (Karim \& Purba, 2018).

Sosialisasi yang dilakukan pada aparat desa kelurahan Lokoboko mengenai pentingnya penginputan data kependudukan melalui web HTML ini sangat bermanfaat karena dapat memudahkan dalam penyimpanan data secara teratur dan rapih. Dalam pendampingan dan pelatihan, aparat desa terlebih dahulu menyiapkan data kependudukan secara manual, komputer/laptop, jaringan internet yang memadai. Selanjutnya tim pengabdian masyarakat menjelaskan langkah-langkah mengoperasikan aplikasi web HTML kepada aparat desa.

Berdasarkan hasil sosialisasi, pendampingan, serta pelatihan penginputan data melalui aplikasi web HTML memberikan dampak yang positif bagi aparat desa dalam penyimpanan data.

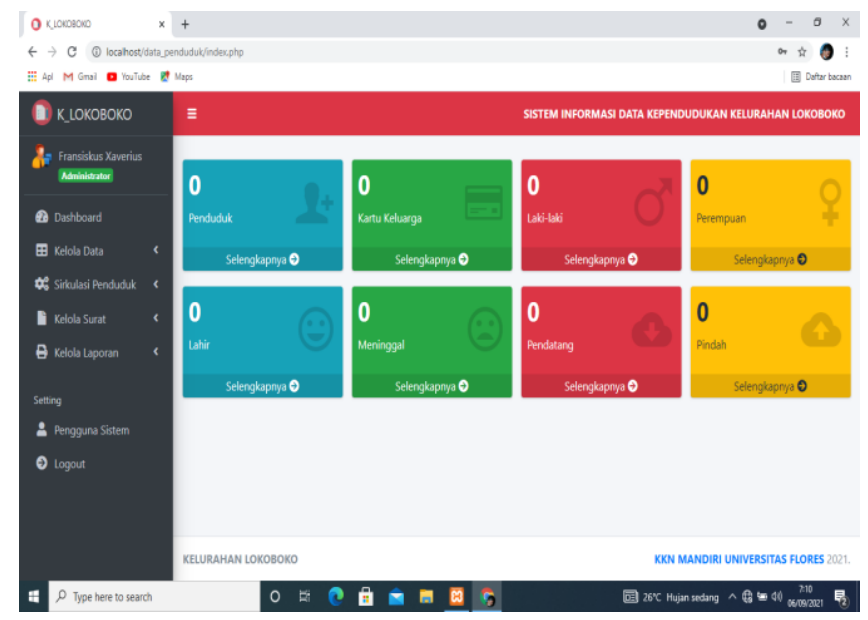

Gambar 1. Perancangan sistem informasi data kependudukan 
Pada gambar 1 dijelaskan bahwa sistem informasi pendataan penduduk dibuat untuk memudahkan dan membantu proses laporan penduduk di Kelurahan Lokoboko, kecamatan Ndona. Menu tampilan dibuat untuk bisa memberikan akses informasi secara mudah dan efisien, karena sisitem ini dapat menginput data penduduk dan menyajikan laporan yang diperlukan oleh pihak kelurahan (Siti \& Witi, 2021). Sistem informasi kependudukan berbasis web ini juga mampu menyajikan informasi yang yang akurat dan relative singkat dalam pendataan dan pencarian data yang tersimpan (Riyadi, 2021).

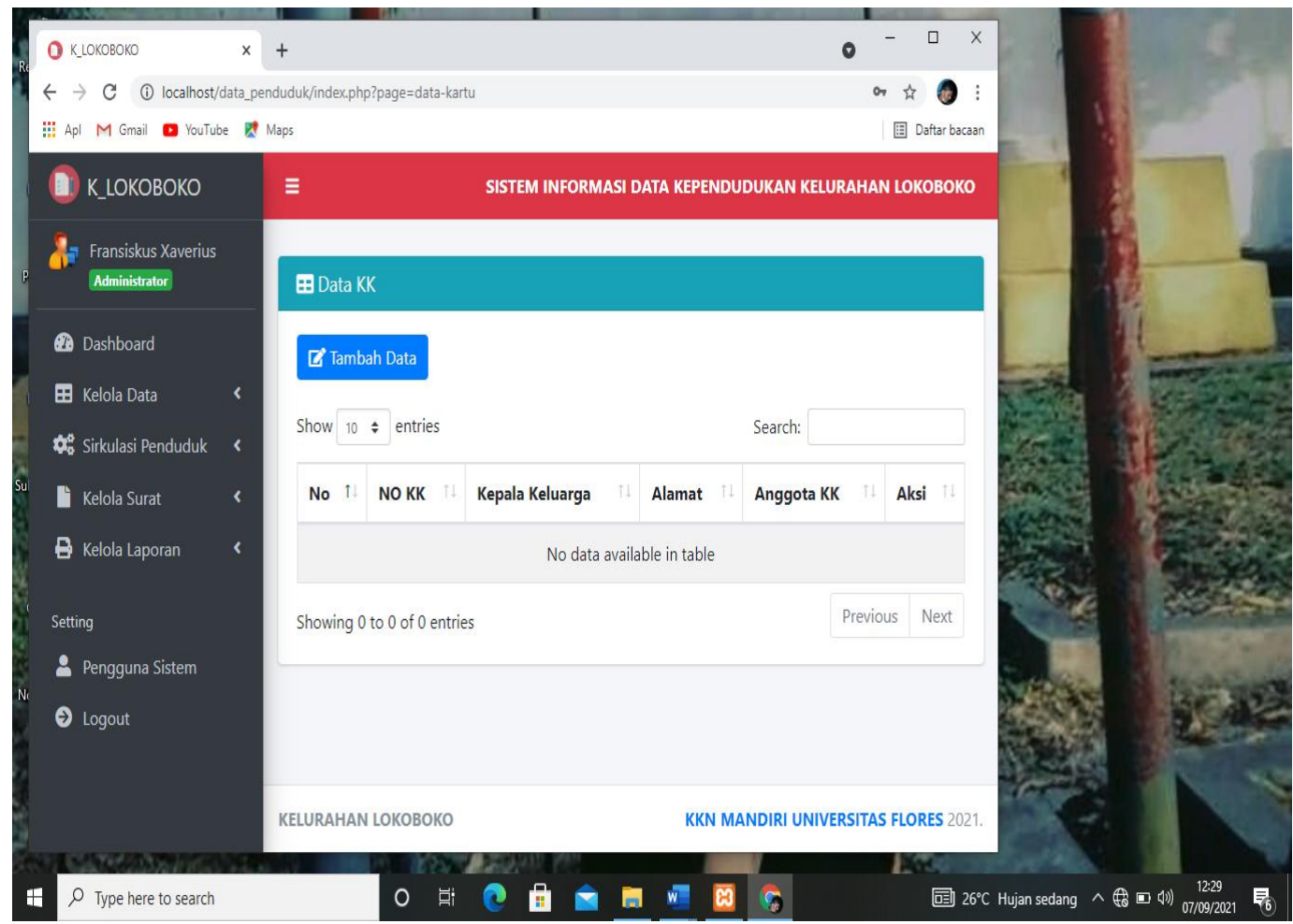

Gambar 2. Form Tambah Keluarga Baru

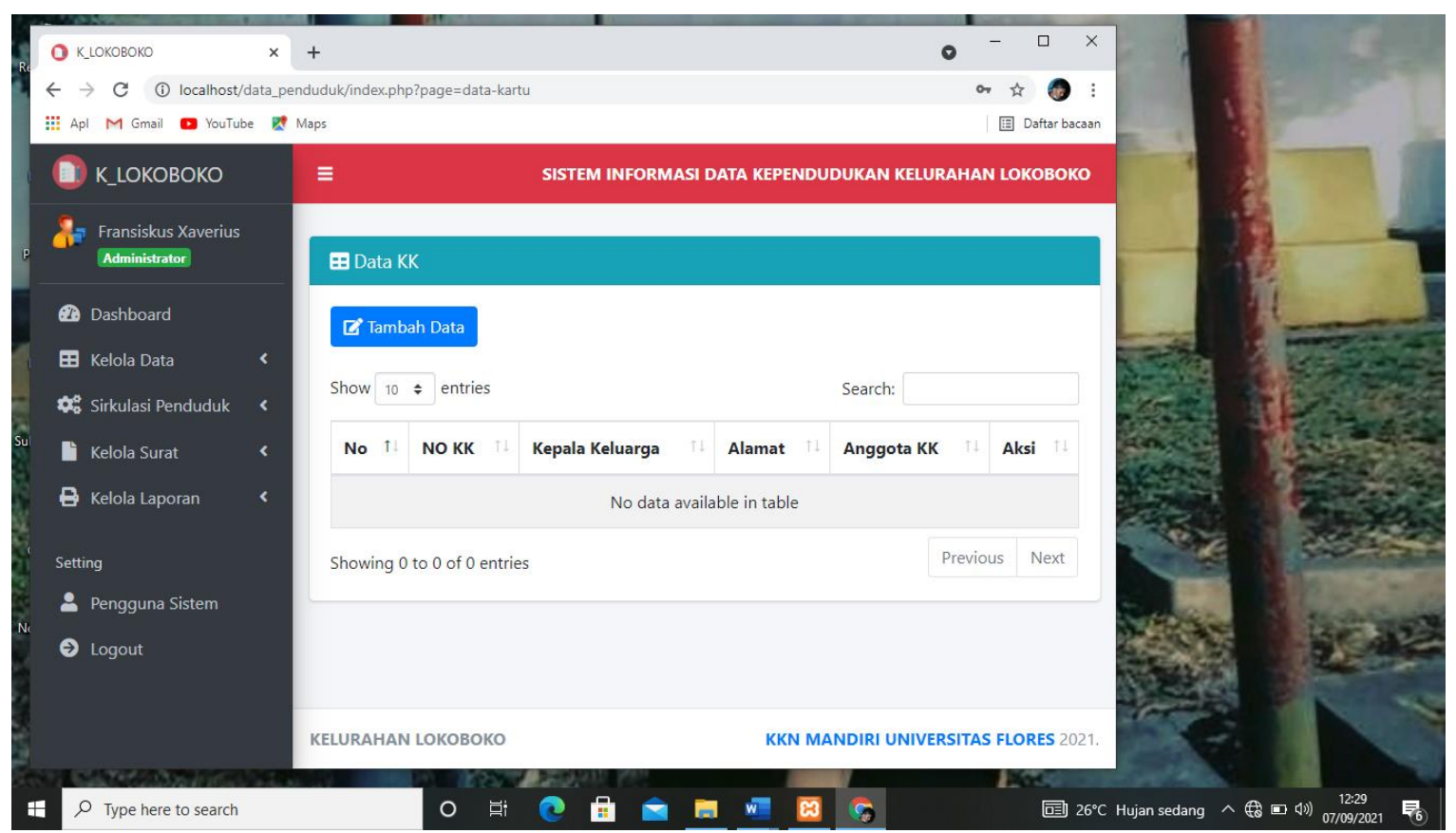

Gambar 3. Form Tambah Penduduk 


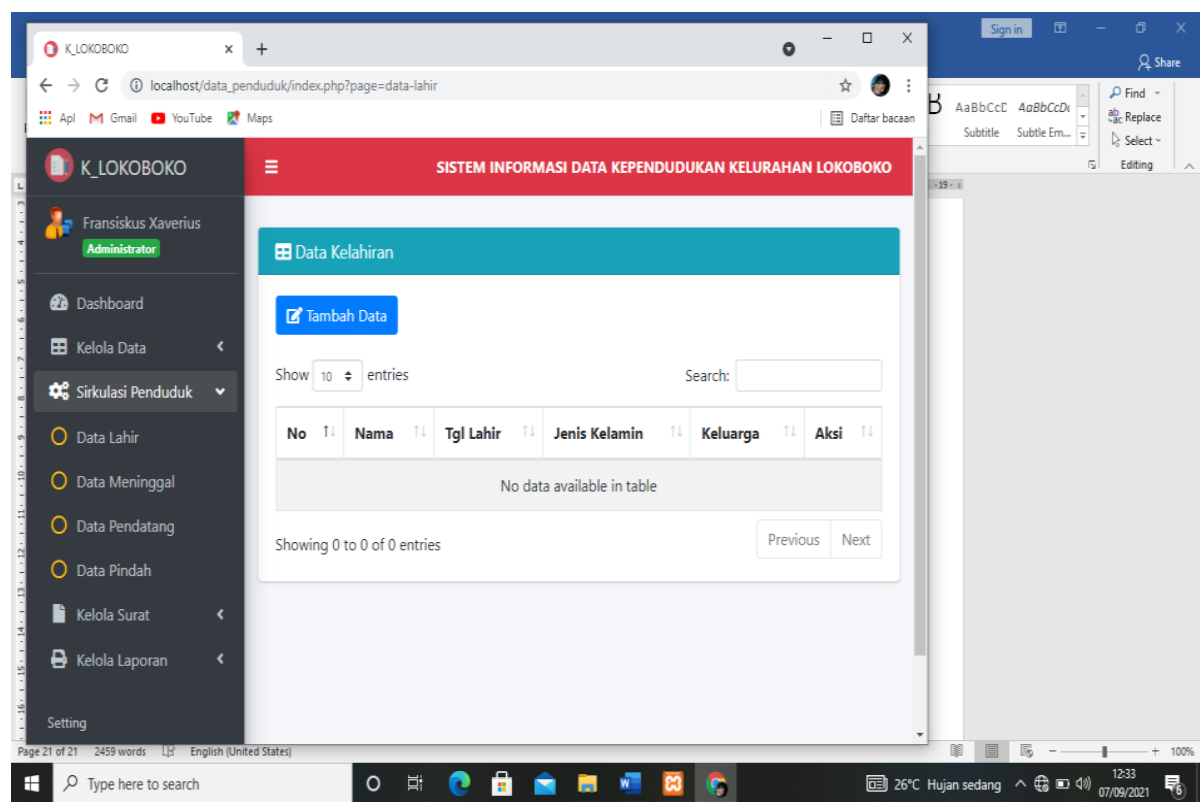

Gambar 4. Form Tampilan data kelahiran

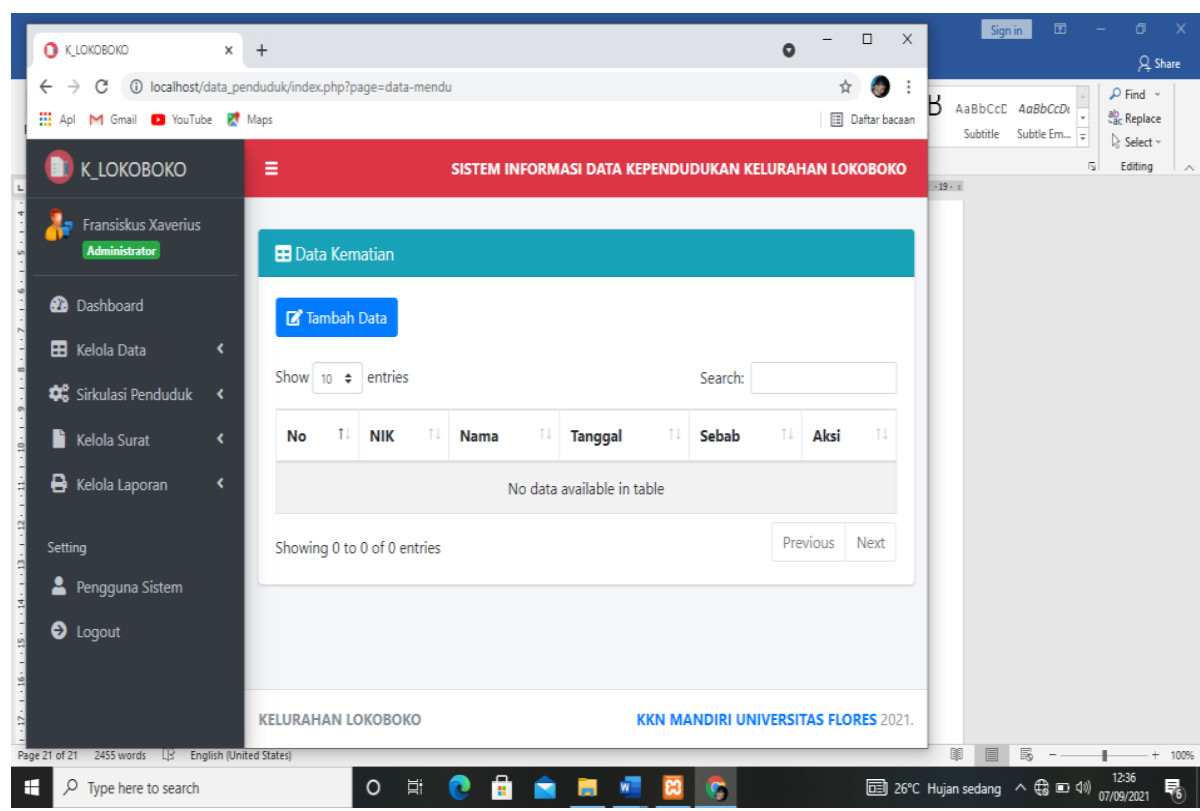

Gambar 5. Form Tampilan data kematian

Berdasarkan gambar 2, 3, 4, dan 5, di tunjukan bahwa tim pengabdi mengembangkan sistem informasi berbasis web yang baru pada kelurahan Lokoboko yang telah terkomputerisasi. Sistem ini akan memudahkan baik para penduduk kelurahan maupun staf dalam mengolah data kependudukan yakni, penambahan keluarga baru, data kelahiran, data kematian, dan data perpindahan penduduk. Sistem informasi berbasis web pada pendataan penduduk ini juga sangat memudahkan masyarakat dan staf kelurahan dalam menginput dan mendata penduduk pada kelurahan Lokoboko Nodna (Ibrahim, Rifai \& Oktarina, 2016)

Penggunaan sistem informasi dalam pendataan kependudukan telah menjadi salah satu kebutuhan yang wajib dipenuhi diera sekarang ini. Sistem informasi dengan mudah dapat membantu dalam pendataan kependudukan baik itu data kelahiran, kematian perpindahan peduduk, terlebih lagi untuk laporan mengenai jumlah penduduk perbulan yang diharapkan (Hayat, Retnadi \& Gunadi, 2016). Penggunaan sistem informasi yang dikembangkan dalam pengabdian ini diharapkan dapat membantu kinerja pemerintah desa Lokoboko Ndona menjadi lebih baik, lebih efisien dan lebih mudah (Paryanta, Sutariyani \& Susilowati, 
2017). Dengan adanya format penyimpanan data dalam data based benrbentuk website, memberikan keuntungan untuk kemudahan dalam mengontrol duplikasi data (Nugroho \& Mulyana, 2018). Data yang telah tersimpan pada data base Website juga lebih aman dan mudah diakses, jika dibandingkan harus disimpan pada format berkas laporan buku (Darmawan,2012) (Siti \& Witi, 2021).

\section{SIMPULAN DAN TINDAK LANJUT}

Dari hasil kegiatan pengabdian kepada masyarakat berupa sosialisasi, pendampingan serta pelatihan penginputan data kependudukan dengan menggunakan web HTML yang diberikan kepada aparat desa kelurahan Lokoboko memberikan dampak yang positif bagi aparat desa dalam penyimpanan data.

Berdasarkan simpulan tersebut, maka disarankan; 1) bagi tim pengabdian masyarakat lanjutan disarankan untuk menggunakan aplikasi web HTML ini dalam penginputan data kependudukan, 2) bagi aparat desa kelurahan lokoboko tetap menggunakan aplikasi web HTML ini dalam setiap penginputan data.

\section{DAFTAR PUSTAKA}

Adani, R. Muhammad. 2018. Jenis Aplikasi Berbasis Web Beserta Contoh Penerapannya. Jakarta: Kencana.

Almais, Agung. 2018. Web Programming. Malang: UNIVERSITAS ISLAM NEGERI MAULANA MALIKIBRAHIM MALANG.

Andoyo, Andreas, dan Ahmad Sujarwadi. 2015. "Sistem Informasi Berbasis Web Pada Desa Tresnomaju Kecamatan Negerikaton Kab. Pesawaran." Jurnal TAM (Technology Acceptance Model ) 3(1):1-9.

Aprilia, P. 2018. Pengertian HTML dan Fungsinya. Jakarta : Kencana.

Azi , W. W. ., \& Anggraini , D. . (2018). SISTEM INFORMASI LOKASI PARIWISATA KABUPATEN ENDE BERBASIS WEB GIS. High Education of Organization Archive Quality: Jurnal Teknologi Informasi, 10(2), 111-116. https://doi.org/10.52972/hoaq.vol10no2.p111-116

Darmawan. D. 2012. Pendidikan teknologi Informasi dan Komunikasi. Bandung: PT. Remaja Rosdakarya.

Hasan, F. ., Agita, P. ., Aditya, D. ., \& Hamonangan, R. . (2021). Pengembangan Sistem Informasi Data Penduduk Desa Cengal. MEANS (Media Informasi Analisa Dan Sistem), 6(2), 142-149. https://doi.org/10.54367/means.v6i2.1514

Hayat, E. A., Retnadi, E., \& Gunadhi, E. (2016). PERANCANGAN SISTEM INFORMASI KEPENDUDUKAN BERBASIS WEB. Jurnal Algoritma, 11(2), 341-349. https://doi.org/10.33364/algoritma/v.11-2.341

Hidayatulloh, S. \& Mulyadi, C. (2015). SISTEM PELAYANAN ADMINISTRASI KEPENDUDUKAN DESA CANDIGATAK BERBASIS WEB. Jurnal IT CIDA. 1(1). 42-55

Ibrahim, A., Rifai, A. \& Oktarina, L. (2016).RANCANG BANGUN APLIKASI PENCATATAN DATA KEPENDUDUKAN KELURAHANPAHLAWAN BERBASIS WEB. Jurnal Sistem Informasi (JSI). 8(1). 947-957

Imaniawan, F. F. D. \& Wati, F. F. (2017). Sistem Informasi Administrasi Kependudukan Berbasis Web Pada Desa Bogangin Sumpiuh. Indonesian Journal on Networking and Security. 7(3). 19

Karim, A \& Purba. E. (2018). Sistem Informasi Pendataan Penduduk Kelurahan Kampung Mesjid Berbasis Web. Seminar Nasional Sains \& Teknologi Informasi (SENSASI). Hal: 537 545 
Nugroho, A., \& Mulyana, A. (2018). Sistem Informasi Data Kependudukan Berbasis Web Di Kantor Kecamatan Cikarang Timur. Jurnal SIGMA, 9(2), 19-24. Retrieved from https://www.jurnal.pelitabangsa.ac.id/index.php/sigma/article/view/382

O’Brien, James A. dan George M. Marakas. 2010. Management Information Systems. 8 ed. New York: McGraw-Hill/Irwin.

Paryanta, P Sutariyani, S. \& Susilowati, D. (2017). Sistem Informasi Administrasi Kependudukan BerbasisWeb Desa Sawahan. Indonesian Journal on Software Engineering (IJSE). 3(2). 7781. https://doi.org/10.31294/ijse.v3i2.2980

Riyadi, S. (2021). SISTEM INFORMASI ADMINISTRASI KEPENDUDUKAN BERBASIS WEB PADA KECAMATAN SABAK AUHKABUPATEN SIAK. Riau Journal of Computer Science. 7(1), 128133. https://doi.org/10.30606/rjocs.v7i02.2179

Rozi, F. \& Listiawan, T(2017). PENGEMBANGAN WEBSITEDAN SISTEM INFORMASIDESA DI KABUPATEN TULUNGAGUNG. JIPI (Jurnal Ilmiah Penelitian dan Pembelajaran Informatika). 2(2). 107 -112. https://doi.org/10.29100/jipi.v2i2.366

Siti Soraya, \& Witi, F. L. (2021). Rancang Bangun Sistem Informasi Pendataan Penduduk Dikantor Kelurahan Kotaratu Kabupaten Ende. SATESI: Jurnal Sains Teknologi Dan Sistem Informasi, 1(2), 38-48. https://doi.org/10.54259/satesi.v1i2.15

Sopiandi. I(2020). SISTEM INFORMASI PENDATAAN PENDUDUK MISKIN BERBASIS WEB. Jurnal Sistem Informasi. 7(2). 97-103

Stair, M. Ralph dan George W. Reynolds. 2010. Principles Of Information Systems: A Managerial Approach (9th Edition). 9 ed. Australia: Thomson Course Technolog. 